\title{
ANALISIS PERBEDAAN LITERASI KEUANGAN NASABAH CREDIT UNION DAN NASABAH BAITUL MAAL WATTAMWIL (SURVEI PADA CREDIT UNION MINO MARTANI SOKARAJA DAN BAITUL MAAL WATTAMWIL MUHAMMADIYAH DANA MENTARI PURWOKERTO)
}

\author{
Hastin Tri Utami, SE, M.Si ${ }^{1}$ \\ ${ }^{1}$ Fakultas Ekonomi dan Bisnis Islam Institut Agama Islam Negeri Purwokerto \\ *hastinazhautami@gmail.com
}

\begin{abstract}
This paper aims to analyze the difference between financial literacy of Credit Union Customers who have financial education and Baitul Maal Wattamwil Customers who do not have financial education in term of behavior, knowledge and attitude. The data was collected by conducting survey. The object of this study is 60 persons consist of 30 credit union customers and 30 BMT customers. The result of this study shows that there is no significance difference between financial literacy of Credit Union Customers who have financial education and Baitul Maal Wattamwil Customers who do not have financial education in term of behavior, knowledge and attitude. This study is only to examine the difference between the financial literacy of the CU customer who has get financial education and BMT customer who has not gotten financial education.

The next study is hoped to analyze the different object before and after given financial education or different objects such as students, banking customers, and housewife. This study is only analyzing in term of three aspects; behavior, knowledge and attitude of the customers. Therefore, the further study can enhance other aspects such as gender, education level, etc.

Keywords : Financial Literacy, Credit Union, BMT.
\end{abstract}

\section{A. PENDAhUluAN}

Perkembangan koperasi simpan pinjam (KSP) dan Unit Simpan Pinjam (USP) terus mengalami peningkatan yang signifikan. Pada bulan Mei 2012 jumlah koperasi simpan pinjam dan koperasi jasa keuangan syariah yang ada di Indonesia yaitu mencapai 9017 unit. Ini artinya terjadi peningkatan jumlah koperasi simpan pinjam sebesar $560 \%$ dalam kurun waktu lima tahun (Harian Kompas, 2012). Perkembangan yang sama juga ditunjukan oleh Unit Usaha Simpan Pinjam dimana pada tahun 2005 jumlah USP sebanyak 36.047 unit yang artinya terjadi peningkatan jumlah USP dan KJKS sebesar 238 persen (Harian Komas, 2012).

Perkembangan yang cukup signifikan tersebut ternyata tidak lantas membuat koperasi simpan pinjam bebas dari masalah dan praktik praktik kecurangan. Beberapa praktik yang disinyalir menjadi sumber permasalahan yaitu : (1) Banyak terjadi penyimpangan koperasi, (2) Banyak KSP yang telah berubah menjadi lembaga keuangan yang hanya mencari keuntungan semata sehingga mengabaikan pelayanan kepada anggota, (3) KSP sekarang cenderung lebih mengutamakan perkreditan atau aktivitas pembiayaan daripada aktivitas menabung bagi para anggotanya (Panggabean, 2010).

Melihat fakta diatas sebaiknya nasabah perlu memiliki pendidikan keuangan atau literasi keuangan yang cukup agar mereka bisa memilih koperasi yang tidak akan merugikan nasabah. Hal ini juga ditegaskan oleh Peter (2012) bahwa banyaknya korban yang timbul dalam kasus penipuan dan penyelewengan dana koperasi disinyalir diakibatkan karena rendahnya literasi keuangan masyarakat. 
Literasi keuangan merupakan sebuah kombinasi kesadaran, pengetahuan, keahlian, sikap dan perilaku yang diperlukan untuk membuat keputusan keuangan yang baik dan pada akhirnya mencapai kondisi keuangan individu yang baik (OECD, 2013). Rendahnya literasi keuangan masyarakat Indonesia terbukti dari suvei yang dilakukan Bank Indonesia. Hasilnya menunjukan bahwa Indonesia memiliki literasi keuangan yang rendah, baik di tingkat nasional dan global. Dibandingkan negara tetangga, Indonesia kalah jauh. Di Filipina tingkat literasi keuangan mencapai 27 persen, Malaysia 66 persen, Singapura 98 persen, sedangkan Indonesia cuma 21,8 persen. (OJK, 2014).

Dewasa ini berkembang satu lembaga keuangan berorientasi non-profit yang mengutamakan pendidikan keuangan untuk masyarakat agar mencapai kemandirian dalam keuangan (financial independence), mengutamakan aktivitas menabung kepada masyarakat. Lembaga ini disebut dengan Credit Union (CU). Berdasarkan perilaku konsumtif masyarakat Indonesia yang besar tanpa diimbangi dengan meningkatkan tabungan disertai dengan praktik koperasi simpan pinjam (KSP) yang tidak mengutamakan gerakan menabung atau simpanan bagi para anggota, maka dibutuhkan sebuah lembaga keuangan yang dapat meningkatkan literasi keuangan (financial literacy) masyarakat Indonesia. Diduga CU mempunyai tujuan mengubah pola pikir masyarakat untuk mengutamakan menabung daripada berhutang dapat meningkatkan literasi keuangan masyarakat Indonesia (Barombo, 2012).

Selain CU, di Indonesia juga berkembang Baitul Maal Wattamwil (BMT). Baitul Maal Wattamwil sama seperti koperasi kredit pada umumnya yang melakukan aktivitas penghimpunan dana dan pembiayaan. Koperasi ini menggunakan sistem bagi hasil dalam operasionalnya namun disinyalir koperasi ini belum menerapkan pendidikan keuangan bagi anggota ataupun calon anggotanya. Selain itu koperasi ini tidak hanya melayani nasabah yang beragama Islam saja, namun setiap masyarakat yang berasal dari agama apapun akan dilayani selama mereka mau mematuhi peraturan yang ditetapkan oleh BMT.

Sebatas kajian literatur dan referensi yang dibaca dan diketahui oleh peneliti, sebagian besar penelitian baik di luar negeri maupun di dalam negeri lebih banyak berfokus pada generasi muda dan pengelola keuangan dalam keluarga. Sedikit dan terbatasnya penelitian mengenai literasi keuangan pada nasabah lembaga keuangan mikro seperti BMT dan Credit Union menjadi menarik. Terlebih fakta menunjukan bahwa sebagian besar nasabah bank syariah adalah nasabah dengan tipe customer emotional (Harian Kompas, 2009). Nasabah dengan tipe ini kurang rasional dan datang dengan rasa percaya yang tinggi kepada lembaga keuangan tersebut sehingga sangat rentan untuk terjebak penipuan jika tidak memiliki literasi keuangan yang tinggi.

Dengan sedikitnya penelitian yang mengangkat tema literasi keuangan pada nasabah lembaga keuangan mikro maka penelitian ini menjadi menarik dan perlu untuk dilakukan agar memberikan kontribusi dan manfaat untuk pengembangan teori dan juga pengembangan penelitian di masa yang akan datang. Berdasarkan uraian diatas maka peneliti tertarik untuk melakukan penelitian "Analisis Perbedaan Literasi Keuangan Nasabah Credit Union Dan Nasabah Baitul Maal Wattamwil (Survei Pada Credit Union Mino Martani Sokaraja Dan Baitul Maal Wattamwil Muhammadiyah Dana Mentari Purwokerto)".

\section{B. TINJAUAN PUSTAKA}

\section{Telaah Pustaka Penelitian Terkait}

Penelitian yang mengkaji tentang literasi keuangan dilakukan oleh Elaine Kempson dan Adele Atkinson (2008) yang berjudul "Measuring and improving 
financial capability: Designing an approach for Kenya". Penelitian ini menghasilkan belum ada pendekatan tunggal untuk mengukur literasi keuangan di tingkat nasional. Namun, beberapa tema umum mulai muncul. Sebagian besar negara tertarik untuk mengetahui lebih lanjut tentang sejauh mana orang mengelola uang mereka secara efektif dan perencanaan untuk masa depan. Sebagian kecil juga mempertimbangkan pengambilan keputusan sehubungan dengan penggunaan jasa keuangan. Ada juga kesepakatan umum bahwa kuesioner harus dirancang untuk mengukur perilaku dan pengetahuan. Tetapi hal ini masih relatif tidak biasa bagi negara-negara untuk mempertimbangkan sikap untuk menjadi aspek kemampuan. Dimana data sikap dikumpulkan itu lebih sering digunakan sebagai variabel deskriptif dari indikator kecenderungan perilaku.

Adele Atkinson and Flore-Anne Messy (2011) meneliti tentang "Assessing financial literacy in 12 countries an OECD Pilot Exercise". Penelitian ini menghasilkan kuesioner tunggal yang memungkinkan sebagai perbandingan lintas negara, kuesioner tunggal harus diberikan pada sampel acak dari populasi di setiap negara. Penelitian dan data ini akan memberikan ketentuan pertama indikator internasional tentang tingkat pengetahuan keuangan, perilaku dan sikap individu dalam pengaturan yang berbeda. Latihan percontohan juga akan menginformasikan finalisasi pertanyaan inti yang diharapkan untuk menjadi standar internasional demi perbandingan internasional tentang melek finansial. Negara-negara yang tidak berpartisipasi dalam latihan percontohan akan didorong untuk menggunakan pertanyaan-pertanyaan inti sebagai produk mandiri atau sebagai bagian dari upaya mereka untuk menetapkan standar nasional tentang literasi keuangan.

Ayu Krishna, Rofi Rofaida, dan Maya Sari meneliti "Analisis Tingkat Literasi Keuangan Di Kalangan Mahasiswa Dan Faktor-Faktor Yang Mempengaruhinya (Survey pada Mahasiswa Universitas Pendidikan Indonesia)" menghasilkan faktor demografi terhadap tingkat literasi keuangan menunjukkan bahwa pria memiliki kemungkinan tingkat literasi keuangan yang lebih rendah dari wanita. Perbedaan usia tidak memberikan pengaruh yang jauh berbeda terhadap tingkat literasi keuangan. Demikian juga dengan lama studi. Untuk asal program studi menunjukan bahwa mahasiswa dengan latar belakang ekonomi kemungkinan memiliki tingkat literasi keuangan yang lebih tinggi dibandingkan dengan mahasiwa dengan latar belakang non ekonomi. Hasil pengujian juga menunjukkan bahwa asal program studi ini memberikan kontribusi paling besar dibandingkan dengan faktor demografi lainnya. Ini menjadi logis karena mahasiswa dengan latar belakang pendidikan ekonomi memperoleh mata kuliah yang berkaitan dengan pengelolaan keuangan. Pengalaman bekerja ternyata juga tidak memberikan pengaruh yang jauh berbeda terhadap tingkat literasi keuangan walaupun secara verifikatif berpengaruh secara signifikan. Hasil lain yang tidak terduga ternyata responden yang memiliki IPK $<3$ kemungkinan memiliki tingkat literasi keuangan yang lebih tinggi jika dibandingkan dengan mahasiswa dengan IPK $>=3$.

Dari uraian diatas terlihat jelas bahwa penelitian mengenai literasi keuangan masih sangat sedikit, selain itu penelitian yang berfokus pada nasabah lembaga keuangan pun sangat sedikit sehingga penelitian ini menjadi menarik dan nantinya bisa menjadi penelitian yang dijadikan rujukan untuk penelitian selanjutnya.

\section{Kerangka Teori}

\section{a) Credit Union}


Menurut World Council of Credit Unions (WOCCU) mendefinisikan Credit Union adalah "not-for-profit cooperation institution" yakni lembaga koperasi yang bukan untuk mencari keuntungan. Credit Union (CU) berasal dari dua kata, yaitu credit dan union. Credit dalam bahasa Latin adalah credere artinya saling percaya. Sedangkan union (unio) berarti kumpulan. Jadi, Credit Union artinya sekumpulan orang yang saling percaya, dalam suatu ikatan pemersatu yang sepakat untuk menabungkan uang mereka sehingga menciptakan modal bersama untuk dipinjamkan kepada anggota dengan tujuan produktif dan kesejahteraan CU. Menurut pendiri CU Pancur Kasih, Drs. Anselmus Robertus Mecer, pertama kali muncul CU di Indonesia pada 1960-an yang mulai dikembangkan dari barat.

CU bagi anggota adalah mengubah pola pikir yaitu dari terbiasa instan langsung memanfaatkan uang saat mendapat pinjaman menjadi menciptakan modal dahulu dengan menabung secara rutin. Jika telah tercipta modal atau tabungan, baru memanfaatkan atau meminjam. Selain itu, CU juga dapat mengubah kebiasaan seseorang dari tidak biasa menabung menjadi biasa menabung. Anggota CU selalu mempunyai uang dalam bentuk tabungan yang terus meningkat dan selalu dapat memanfaatkan tabungan untuk meningkatkan jumlah untuk menciptakan aset.

CU mempunyai tujuan untuk meningkatkan kondisi keuangan para anggotanya. Sampai pada tingkat mandiri dalam bidang keuangan (financial independence). Seseorang dapat dikatakan sudah mandiri dalam bidang keuangan apabila aset-aset yang dimiliki dapat menghasilkan pendapatan dan pendapatan dari aset-aset tersebut dapat membiayai semua pengeluaran hidupnya. Mandiri dalam bidang keuangan baru terjadi apabila seorang anggota mampu mencapai setidaknya kelas "Berkecukupan". Kelas-kelas secara ekonomi di masyarakat dapat dilihat pada gambar 1. Ciri-ciri berkecukupan adalah pendapatan pasif sudah mampu menutupi biaya hidup sehari- hari. (Munaldus dkk, 2012:xxii).

\section{b) Baitul Maal Wattamwil (BMT)}

Baitul Mal Wattamwil (BMT) terdiri dari dua istilah, yaitu baitul maal dan baitut tamwil. Baitul maal lebih mengarah pada usaha-usaha pengumpulan dan penyaluran dana yang non profit, seperti zakat, infak dan shodaqoh. Sedangkan baitut tamwil sebagai usaha pengumpulan dan dan penyaluran dana komersial (Prof. H A. Djazuli: 2002).

\section{c) Teori The Bottom of the Pyramid}

Menurut C.K. Prahalad :

The bottom of the (economic) pyramid consists of the 4 billion people living on less than \$2 per day. For more than 50 years, the World Bank, donor nations, various aid agencies, national governments, and, lately, civil society organizations have all done their best, but they were unable to eradicate poverty. (Bagian bawah (ekonomi) piramida terdiri dari 4 milyar orang hidup dengan kurang dari \$ 2 per hari. Selama lebih dari 50 tahun, Bank Dunia, negara-negara donor, berbagai lembaga bantuan, pemerintah nasional, dan belakangan, organisasi masyarakat sipil melakukan yang terbaik, tetapi mereka tidak mampu untuk memberantas kemiskinan).

C.K. Prahalad dalam bukunya The Fortune at the Bottom of the Pyramid: "If we stop thinking of the poor as victims or as a burden and start recognizing them as resilient and creative entrepreneurs and value-conscious consumers, a whole new world of opportunity will open up". 
(Jika kita berhenti memikirkan orang miskin sebagai korban atau sebagai beban dan mulai mengakui mereka sebagai pengusaha ulet dan kreatif dan konsumen yang sadar nilai, seluruh peluang dunia baru akan terbuka).

Prahalad menunjukkan bahwa empat miliar miskin dapat menjadi mesin putaran berikutnya dalam perdagangan global dan kemakmuran, dan dapat menjadi sumber inovasi. Melayani Piramida Bawah pelanggan mengharuskan perusahaan besar bekerja sama dengan organisasi masyarakat sipil dan pemerintah daerah. Selain itu, pengembangan pasar di Piramida bawah juga akan menciptakan jutaan pengusaha baru di tingkat akar rumput.

Salah satu cara untuk membantu orang miskin (golongan kelas ekonomi bawah) ini adalah dengan lembaga microcredit yaitu CU dan BMT. Dengan teknologi yang lebih murah, akan lebih ekonomis dan efisien untuk meminjamkan sejumlah kecil uang kepada orang dengan aset bahkan mikro. Lembaga ini berkembang pesat di Asia Selatan khususnya Bangladesh. Sebuah laporan perbankan India berpendapat bahwa jaringan keuangan mikro (disebut "Sa-Dhan" di India) membantu orang miskin dan memungkinkan bank untuk meningkatkan bisnis mereka.

\section{d) Literasi Keuangan (Financial Literacy)}

OECD mendefinisikan literasi keuangan sebagai

A combination of awareness, knowledge, skills, attitude and behaviours necessary to make sound financial decisions and ultimately achieve individual wellbeing.

(sebuah kombinasi kesadaran, pengetahuan, keahlian, sikap dan perilaku yang diperlukan untuk membuat keputusan keuangan yang baik dan pada akhirnya mencapai kondisi keuangan individu yang baik).

Ada empat pola pengelolaan uang yang dipraktikkan oleh masyarakat, yaitu:

a. Utang dulu $=>$ dapat uang $=>$ bayar utang $=>$ belanja $=>$ utang lagi

b. Dapat uang $=>$ belanja habis

c. Dapat uang $=>$ belanja $=>$ menabung (dari uang sisa kalau ada)

d. Dapat uang $=>$ bayar utang $=>$ menabung/investasi $=>$ belanja

Menurut Robert T. Kiyosaki, "Pendidikan keuangan memungkinkan seseorang memproses berbagai informasi keuangan dan memiliki pengetahuan keuangan."(Munaldus, 2012).

Pola pengelolaan uang yang sudah mencapai tingkat literasi keuangan adalah pola keempat, yakni: dapat uang $\Rightarrow$ bayar utang $\Rightarrow$ menabung /berinvestasi => belanja. Penjelasannya adalah setiap kali mendapat uang, yang harus diutamakan adalah mengangsur hutang-hutang, jika kewajiban sudah terpenuhi lanjutkan dengan menabung atau berinvestasi. Terakhir adalah belanja. Mengusahakan menabung $10 \%$ dari uang yang didapatkan.

\section{METODE PENELITIAN DAN TEKNIK ANALISIS DATA}

\section{a. Metode Penelitian}

a. Jenis Penelitian

Penelitian ini merupakan penelitian kuantitatif yang bertujuan untuk mengetahui perbedaan literasi keuangan antara nasabah CU dan BMT dengan menggunakan metode survey. Untuk pendekatan kuantitatif penelitian ini masuk dalam jenis penelitian kausal komparatif yaitu penelitian yang digunakan untuk 
membandingkan antara dua kelompok atau lebih dari satu variabel tertentu. (Sugiyono, 2009:54).

b. Lokasi Penelitian

Penelitian ini dilaksanakan di dua tempat berbeda yaitu:

- Credit Union Mino Martani Sokaraja. Jalan Raya Banyumas Sokaraja (Depan Perumahan Sokaraja)

- BMT Dana Mentari Purwokerto. Utara Pasar Karanglewas Purwokerto

c. Objek Penelitian Objek dalam penelitian ini adalah nasabah CU Mino Martani Sokaraja dan nasabah KJKS BMT Dana Mentari Purwokerto.

d. Populasi dan Sampel Penelitian

Populasi dalam penelitian ini adalah seluruh pengurus dan anggota CU Mino Martani Sokaraja dan BMT Dana Mentari Purwokerto. Penelitian ini termasuk dalam penelitian kausal komparatif, yaitu penelitian yang membandingkan 2 kelompok dengan sampel independen. Oleh karena itu jumlah minimal sampel yang diambil sebesar 30 dari masing-masing kelompok. (Gay dan Diehl, 1996: 140141)

e. Teknik Pengumpulan Data

- Teknik Pengumpulan Data Primer

Yakni pengumpulan data yang dilakukan secara langsung pada lokasi penelitian atau objek yang diteliti atau data yang diperoleh ini disebut data primer. Dalam hal ini data diperoleh dengan cara wawancara dan pengisisan kuesioner. Kuesioner yang digunakan dalam penelitian ini mengadaptasi penuh dari kuesioner survey pengukuran literasi keuangan di 12 negara (OECD, 2011). Survey tersebut diambil dari 26 pertanyaan survey literasi keuangan yang mencakup aspek perilaku, pengetahuan dan sikap di 12 negara.

- Teknik Pengumpulan Data Sekunder

Yakni data yang diperoleh untuk mendukung data primer. Data sekunder yang digunakan antara lain studi kepustakaan dan dokumentasi.

f. Definisi Operasional Variabel

OECD mendefinisikan literasi keuangan sebagai $A$ combination of awareness, knowledge, skills, attitude and behaviours necessary to make sound financial decisions and ultimately achieve individual wellbeing. (sebuah kombinasi kesadaran, pengetahuan, keahlian, sikap dan perilaku yang diperlukan untuk membuat keputusan keuangan yang baik dan pada akhirnya mencapai kondisi keuangan individu yang baik)

Dari definisi yang dijelaskan di atas, maka literasi keuangan dapat diukur dengan beberapa aspek yaitu aspek perilaku, aspek pengetahuan dan aspek sikap.

- Aspek Perilaku

Aspek Perilaku diukur melalui ada tidaknya Anggaran Rumah Tangga, Pengetahuan Jasa Keuangan, Jasa Keuangan Yang Sedang Digunakan, Pilihan Jasa Keuangan, Pertimbangan Sebelum Berinvestasi, Informasi Yang Paling Mempengaruhi Keputusan, Kemampuan Pendapatan Tiap Bulan Dalam Memenuhi Kebutuhan, Cara Menutup Kekurangan Pendapatan, Cara Menabung, Recovery Ability, Stabilitas Pendapatan.

- Aspek Pengetahuan

Aspek Pengetahuan diukur melalui pengetahuan dasar mengenai konsepkonsep dasar keuangan seperti Pengetahuan Pembagian Uang 
Pengetahuan Time Value Of Money, Pengetahuan Bunga Pinjaman, Pengetahuan Resiko Investasi.

- Aspek Sikap

Aspek Sikap diukur melalui pertimbangan kemampuan dalam membayar angsuran sebelum membeli barang secara kredit, sikap dalam memikirkan kebutuhan hari ini dan kebutuhan hari besok, prioritas dalam belanja dan menabung, tepat atau tidaknya membayar utang/tagihan, menabung agar mempunyai dana cadangan untuk kondisi darurat, mengontrol sendiri keuangan pribadi, perencanaan keuangan jangka panjang, sikap terhadap uang, setuju atau tidaknya meminjam uang pada rentenir, setuju atau tidaknya meminjam uang pada koperasi, bank atau credit union, kepemilikan asuransi biaya pendidikan dan kesehatan, kepemilikan tabungan masa tua, menabung kalau ada uang sisa dari uang bulanan, prioritas dalam membayar hutang dulu baru kemudian belanja, penjualan harta/barang untuk memenuhi kebutuhan tak terduga.

\section{b. Teknik Analisis Data}

Uji Asumsi Klasik Normalitas

Uji normalitas data digunakan untuk mengetahui apakah data berdistribusi normal atau tidak pada kuesioner yang disebar. Uji normalitas penelitian ini dilakukan dengan uji statistik non-parametrik Kormogolov Smirnov. Jika nilai asympotic sig (two tailed) $>$ alpha $(\alpha=0,05)$ maka nilai residual memenuhi asumsi klasik atau berdistribusi normal (Ghozali, 2009)

c. Pengujian Hipotesis

Hasil jawaban kuesioner dari responden akan dianalisis menggunakan analisis kuantitatif. Metode analisis kuantitatif yang sesuai adalah menggunakan metode statitisk nonparametrik yaitu uji beda Mann Whitney $U$. Di mana perhitungannya menggunakan program SPSS 17.0. Berikut ini langkah-langkah untuk melakukan uji Mann Whitney U:

- Menentukan hipotesis statistik

- Menentukan tingkat signifikansi

Tingkat signifikansi menggunakan $=0,05$

- Menentukan nilai Uhitung dengan level of significance = 0,05 dan Utabel (n1,n2)

- Membandingkan nilai Uhitung dengan Utabel dengan kriteria pengujian berikut:

HO diterima, jika : Uhitung $\geq$ Utabel $(\alpha)$

Ha diterima, jika : Uhitung $<$ Utabel $(\alpha)$

- Menarik kesimpulan

\section{HASIL DAN PEMBAHASAN}

\section{Hasil}

\section{a. Gambaran Umum Responden}

1) Identitas Responden Berdasarkan Jenis Kelamin

\begin{tabular}{|c|c|c|c|}
\hline No & Keterangan & Jumlah & Presentase \\
\hline 1 & Pria & 37 & $62 \%$ \\
\hline 2 & Wanita & 23 & $38 \%$ \\
\hline
\end{tabular}


2) Identitas Responden Berdasarkan Geografis Tempat Tinggal

\begin{tabular}{llll}
\hline No & Keterangan & Jumlah & Presentase \\
\hline 1 & Desa & 30 & $50 \%$ \\
2 & Kota Kecil & 17 & $28 \%$ \\
3 & Kota & 13 & $22 \%$ \\
4 & Kota Besar & 0 & $0 \%$ \\
5 & Kota Sangat Besar & 0 & $0 \%$ \\
\hline Jumlah Kuesioner & 60 & \\
\hline
\end{tabular}

3) Identitas Responden Berdasarkan Jumlah Anak

\begin{tabular}{llll}
\hline No & Keterangan & Jumlah & Presentase \\
\hline 1 & 0 & 12 & $20 \%$ \\
2 & 1 & 12 & $20 \%$ \\
3 & 2 & 19 & $32 \%$ \\
4 & 3 & 16 & $27 \%$ \\
5 & 4 & 1 & $2 \%$ \\
\hline \multicolumn{2}{l}{ Jumlah Kuesioner } & 60 &
\end{tabular}

4) Identitas Responden Berdasarkan Jumlah Tanggungan

\begin{tabular}{llll}
\hline No & Keterangan & Jumlah & Presentase \\
\hline 1 & 1 & 1 & $2 \%$ \\
2 & 2 & 11 & $18 \%$ \\
3 & 3 & 10 & $17 \%$ \\
4 & 4 & 16 & $27 \%$ \\
5 & $>5$ & 22 & $37 \%$ \\
\hline \multicolumn{2}{l}{ Jumlah Kuesioner } \\
\hline
\end{tabular}

5) Identitas Responden Berdasarkan Penanggungjawab Keuangan

\begin{tabular}{lllr}
\hline No & Keterangan & Jumlah & Presentase \\
\hline 1 & Responden Sendiri & 16 & $27 \%$ \\
2 & Responden dan Pasangan & 25 & $42 \%$ \\
& Responden dan Anggota & & \\
3 & Keluarga & 10 & $17 \%$ \\
4 & Pasangan Responden & 3 & $5 \%$ \\
5 & Anggota Keluarga & 6 & $10 \%$ \\
\hline Jumlah Kuesioner & \multicolumn{3}{c}{60} \\
\end{tabular}

6) Identitas Responden Berdasarkan Usia

\begin{tabular}{lllr}
\hline No & Keterangan & Jumlah & Presentase \\
\hline 1 & $20-30$ & 16 & $27 \%$ \\
2 & $31-40$ & 19 & $32 \%$ \\
3 & $41-50$ & 17 & $28 \%$ \\
4 & $51-60$ & 7 & $12 \%$
\end{tabular}




\begin{tabular}{llll}
5 & $>60$ & 1 & $2 \%$ \\
\hline Jumlah Kuesioner & & 60 & \\
\hline
\end{tabular}

7) Identitas Responden Berdasarkan Pendidikan Terakhir

\begin{tabular}{llll}
\hline No & Keterangan & Jumlah & Presentase \\
\hline 1 & SD & 0 & $0 \%$ \\
2 & SMP & 14 & $23 \%$ \\
3 & SMA & 38 & $63 \%$ \\
4 & Perguruan Tinggi & 8 & $13 \%$ \\
\hline Jumlah Kuesioner & \multicolumn{3}{c}{60} \\
\hline
\end{tabular}

\section{b. Statistik Deskriptif Aspek Perilaku}

\begin{tabular}{|l|l|l|l|l|l|}
\hline & & & & & $\begin{array}{l}\text { Std. } \\
\text { Deviation }\end{array}$ \\
\hline X1_1 & 60 & 0 & 1 & .75 & .437 \\
X1_2 & 60 & 1 & 5 & 2.30 & .997 \\
X1_3 & 60 & 1 & 4 & 2.00 & .902 \\
X1_4 & 60 & 1 & 4 & 2.63 & .780 \\
X1_5 & 60 & 0 & 2 & 1.25 & .704 \\
X1_6 & 60 & 0 & 4 & 2.05 & 1.682 \\
X1_7 & 60 & 0 & 1 & .78 & .415 \\
X1_8 & 60 & 0 & 7 & 1.30 & 2.533 \\
X1_9 & 60 & 1 & 3 & 1.73 & .710 \\
X1_10 & 60 & 1 & 3 & 1.88 & .613 \\
X1_11 & 60 & 0 & 1 & .83 & .376 \\
Valid N (listwise) & 60 & & & & \\
\hline
\end{tabular}

Sumber : Data Primer Yang Diperoleh (2018)

1) Anggaran Rumah Tangga ( $\left.X 1 \_1\right)$

Pertanyaan mengenai anggaran rumah tangga bertujuan untuk mengetahui apakah keluarga responden melakukan perencanaan anggaran rumah tangga meskipun sederhana. Jika responden menjawab yam aka akan diberi skor 1 dan apabila menjawab tidak maka akan diberi nilai 0. Dari tabel tersebut diatas diperoleh nilai rata-rata 0,75 . Sehingga dapat disimpulkan bahwa responden belum membuat anggaran rumah tangga.

2) Pengetahuan Jasa Keuangan (X1_2)

Pertanyaan bertujuan untuk mengetahui seberapa banyak jasa keuangan yang diketahui oleh responden. Responden diperkenankan untuk menjawab lebih dari satu jawaban. Setiap jawaban responden bernilai satu dan diakumulasi. Dari hasil analisis statistic deskriptif diperoleh nilai rata-rata 2,30. Sehingga bisa ditarik kesimpulan jasa keuangan yang diketahui oleh responden rata-rata hanya dua jenis.

3) Jasa Keuangan Yang Sedang Digunakan (X1_3)

Pertanyaan bertujuan untuk mengetahui jasa keuangan apa yang saat ini sedang digunakan oleh responden. Masing-masing jawaban bernilai 1. Dari hasil 
analisis statistickdeskriptif diperoleh nilai rata-rata 2. Sehingga dapat disimpulkan bahwa rata-rata responden mengakses dua jasa keuangan.

4) Pilihan Jasa Keuangan (X1_4)

Pertanyaan ini bertujuan untuk mengetahui produk jasa keuangan apa yang menarik bagi responden selain produk keuangan yang sekarang sedang digunakan. Dari hasil analisis statistik deskriptif diperoleh nilai rata-rata 2,63 yang artinya responden tertarik rata-rata dengan dua jenis jasa keuangan.

5) Pertimbangan Sebelum Berivestasi (X1_5)

Pertanyaan bertujuan untuk mengetahui apa yang menjadi bahan pertimbangan responden sebelum melakukan investasi. Responden akan diberikan skor dengan ketentuan :

a) Saya tidak mempertimbangkan apapun (skor 0)

b) Saya mempertimbangkan ketentuan tabungan atau pinjaman dari satu perusahaan (skor 1)

c) Saya membandingkan ketentuan tabungan dan pinjaman dari beberapa perusahaan (skor 2)

Rata-rata jawaban yang diperoleh adalah sebesar 1,25 yang artinya responden mempertimbangkan ketentuan menabung dan pinjaman dari satu perusahaan.

6) Informasi yang paling mempengaruhi keputusan (X1_6)

Tujuan dari pertanyaan ini adalah untuk mengidentifikasi sumber informasi apa yang paling mempengaruhi responden dalam membuat keputusan keuangan. Setiap responden hanya diperkenankan menjawab 1 jawaban saja. Hasil rata-rata yang diperoleh adalah nilai 2,05 yang artinya sebagian besar responden paling terpengaruh dengan nasihat dari teman/relasi yang bekerja di industri jasa keuangan.

7) Kemampuan Pendapatan Tiap Bulan Dalam Memenuhi Kebutuhan (X1_7)

Pertanyaan ini bertujuan untuk mengetahui apakah pengeluaran dalam satu tahun terakhir lebih banyak daripada pendapatan mereka. Jika responden menjawab ya maka akan mendapat skor 0 dan jika menjawab tidak skor adalah 1. Dari statistik deskriptif diatas didapatkan rata-rata jawaban yaitu 0,78 yang artinya pendapatan responden belum mampu menutup pengeluaran.

8) Cara Menutup Kekurangan Pendapatan (X1_8)

Pertanyaan ini merupakan kelanjutan dari pertanyaan sebelumnya (X1_7). Responden diperkenankan untuk menjawab pertanyaan ini jika pertanyaan sebelumnya menjawab Ya. Responden diberikan pilihan untuk menjawab cara menambah sumber keuangan. Jawaban hanya diperbolehkan satu pilihan saja. Rata-rata jawaban yang terlihat dari statistic deskriptif adalah 1,30 yang artinya responden akan mengambil uang dari tabungan untuk menambah sumber keuangan jika pengeluaran lebih besar dari pendapatan.

9) Cara Menabung (X1_9)

Pertanyaan ini bertujuan untuk mengetahui cara responden menyimpan atau menabungkan uangnya. Jawaban responden boleh lebih dari satu pilihan. Rata-rata jawaban responden adalah sebesar 1,73 yang artinya responden ratarata menabung dengan menggunakan satu media saja.

10) Recovery Ability (X1_10)

Pertanyaan ini bertujuan untuk mengetahui berapa lama waktu yang diperlukan responden untuk menutup kekurangan pendapatan yang mereka alami tanpa harus berhutang. Responden diberikan pilihan sebagai berikut : 

a) Kurang dari 1 minggu (diberi skor 1 )
b) Antara 1 minggu - 1 bulan (diberi skor 2)
c) Antara 1 bulan -3 bulan (diberi skor 3 )
d) Antara 3 bulan -6 bulan (diberi skor 4 )
e) Lebih dari 6 bulan (diberi skor 5)
Rata-rata jawaban responden berada pada angka 1,88. Yang artinya responden mampu menutup kekurangan pendapatan dalam waktu kurang dari 1 minggu.

11) Stabilitas Pendapatan (X1_11)

Pertanyaan ini bertujuan untuk mengetahui apakah pendapatan responden sudah mampu untuk menutup pengeluaran atau belum. Jika repsonden menjawab ya akan diberikan skor 1 dan apabila belum maka akan diberikan skor 0. Rata-rata jawaban yang diperoleh adalah 0,83 yang artinya rata-rata pendapatan responden belum mampu untuk menutup pengeluaran responden.

\section{c. Statistik Deskriptif Aspek Pengetahuan Responden}

\begin{tabular}{|l|r|r|r|r|r|}
\hline & & & & \multicolumn{1}{l|}{$\begin{array}{l}\text { Dtd. } \\
\text { Deviation }\end{array}$} \\
\hline & N & Min & Max & Mean & Desiptive Statistics \\
\hline X2_1 & 60 & 0 & 5 & 4.50 & 1.513 \\
X2_2 & 60 & 0 & 4 & 2.50 & 1.524 \\
X2_3 & 60 & 0 & 5 & 3.58 & 2.272 \\
X2_4 & 60 & 0 & 3 & 1.65 & 1.233 \\
X2_5 & 60 & 0 & 5 & 2.83 & 2.499 \\
X2_6 & 60 & 1 & 4 & 2.40 & .785 \\
Valid N (listwise) & 60 & & & & \\
\hline
\end{tabular}

Sumber : Data Primer yang diolah (2018)

1) Pengetahuan Pembagian Uang (X2_1)

Pertanyaan bertujuan untuk mengetahui apakah responden mampu menjawab pertanyaan mengenai pembagian uang. Pertanyaan yang diberikan yaitu Rp10.000.000 dibagi 5. Jawaban betul yaitu Rp2.000.000. Jika responden menjawab benar maka akan diberikan poin 5 . Jika salah dan atau tidak menjawab maka akan diberikan nilai 0 . Rata-rata jawaban yang responden berikan adalah 4,5 yang artinya responden sebagian besar menjawab benar.

2) Pengetahuan Time Value Of Money 1 (X2_2)

Dari hasil analisis tersebut diatas rata-rata jawaban responden 2,50 yang artinya dapat diambil kesimpulan bahwa jawaban responden sebagian besar belum benar.

3) Pengetahuan Time Value Of Money 2 (X2_3)

Dari hasil analisis tersebut diatas rata-rata jawaban responden 3,58 yang artinya dapat diambil kesimpulan bahwa jawaban responden secara umum belum benar.

4) Pengetahuan Time Value Of Money 3 (X2_4)

Dari tabel hasil analisis statistik deskriptif diatas diperoleh nilai ratarata jawaban responden adalah 1,65. Yang atinya dapat diambil kesimpulan jawaban responden secara umum belum benar. 
5) Pengetahuan Bunga Pinjaman (X2_5)

Pertanyaan Ini untuk memastikan apakah responden memberikan bunga kepada temannya jika meminjamkan uang kepada temannya selama satu hari. Jika responden menjawab 0 atau tidak memberikan bunga maka akan diberi poin 5 dan jika menjawab selain 0 atau tidak menjawab maka nilainya adalah 0 . Rata-rata jawaban responden adalah 2,83 yang artinya responden secara umum belum menjawab dengan benar.

6) Pengetahuan Risiko Investasi (X2_6)

Pertanyaan dalam aspek pengetahuan risiko investasi ini terdiri dari 4 item. Masing-masing jawaban benar akan diberi poin satu dan total jawaban akan diakumulasikan. Berdasarkan hasil statistik deskriptif diatas diperoleh nilai rata-rata 2,40 sehingga dapat diambil kesimpulan bahwa responden belum menjawab benar secara umum.

\section{d. Statistik Deskriptif Aspek Sikap Responden}

Descriptive Statistics

\begin{tabular}{|l|l|l|l|l|}
\hline Ket & N & Min & Max & Mean \\
\hline Sikap & 60 & 37 & 55 & 45,5 \\
Valid & 60 & & & \\
\hline
\end{tabular}

Sumber : Data Primer Yang Diolah (2018)

Dalam aspek sikap responden terdapat 15 item pertanyaan yang harus dijawab oleh responden. Responden diberikan pilihan jawaban Sangat setuju (poin 4), Setuju (poin 3), Tidak setuju (poin 2) dan Sangat tidak setuju (poin 1). Berdasarkan hasil analisis statistic deskriptif diatas didapatkan nilai rata-rata 45,5 yang jika dibagi 15 diperoleh hasil 3,03. Yang artinya jawaban responden rata-rata pada jawaban Setuju.

\section{e. Pengujian Hipotesis}

1) Hipotesis 1

HO: Tidak terdapat Perbedaan literasi keuangan nasabah CU yang mendapat pendidikan keuangan dengan anggota BMT yang tidak mendapat pendidikan keuangan dilihat dari aspek perilaku.

H1: Terdapat Perbedaan literasi keuangan nasabah CU yang mendapat pendidikan keuangan dengan anggota BMT yang tidak mendapat pendidikan keuangan dilihat dari aspek perilaku.

Hasil Uji Independent Sample Uji Mann Whitney U Test Aspek Perilaku dapat dilihat pada tabel dibawah ini :

Ranks

\begin{tabular}{|l|l|r|r|r|}
\hline & & & & \multicolumn{2}{l|}{$\begin{array}{l}\text { Sum of } \\
\text { Grup }\end{array}$} & N & Mean Rank & \multicolumn{2}{l|}{ Ranks } \\
\hline Perilaku & 100 & 30 & 28.32 & 849.50 \\
& 200 & 30 & 32.68 & 980.50 \\
& Total & 60 & & \\
\hline
\end{tabular}

Test Statistics ${ }^{\mathrm{a}}$

\begin{tabular}{|l|r|}
\hline \multicolumn{2}{|c|}{ Perilaku } \\
\hline Mann-Whitney U & 384.500 \\
Wilcoxon W & 849.500 \\
Z & -.973
\end{tabular}


Uji hipotesis 1 dilakukan untuk menguji kuisioner utama berupa essay yang mencerminkan aspek literasi keuangan dari aspek perilaku. Berdasarkan hasil analisis statistik diatas Uhitung aspek perilaku sebesar 384,5 lebih besar dari nilai Utabel sebesar 317 dan nilai signifikansinya 0,331 lebih besar dri $\alpha=$ 0,05 . Dari hasil analisis tersebut maka hipotesis satu yaitu terdapat perbedaan literasi keuangan nasabah CU yang mendapat pendidikan keuangan dengan anggota BMT yang tidak mendapat pendidikan keuangan dilihat dari aspek perilaku ditolak.

2) Hipotesis 2

H2: Terdapat perbedaan literasi keuangan nasabah CU yang mendapat pendidikan keuangan dengan nasabah BMT yang tidak mendapat pendidikan keuangan dilihat dari aspek pengetahuan.

HO: Tidak terdapat perbedaan literasi keuangan nasabah CU yang mendapat pendidikan keuangan dengan nasabah BMT yang tidak mendapat pendidikan keuangan dilihat dari aspek pengetahuan.

Hasil Uji Independent Sample Uji Mann Whitney $U$ test Aspek Pengetahuan dapat dilihat dalam tabel sebagai berikut:

Ranks

\begin{tabular}{|l|c|c|c|c|}
\hline \multicolumn{2}{|c|}{ Grup } & N & Mean Rank & Sum of Ranks \\
\hline Pengetah & 100 & 30 & 32.13 & 964.00 \\
uan & 200 & 30 & 28.87 & 866.00 \\
& Total & 60 & & \\
\hline
\end{tabular}

Test Statistics

\begin{tabular}{|l|r|}
\hline & Pengetahuan \\
\hline Mann-Whitney U & 401.000 \\
Wilcoxon W & 866.000 \\
Z & -.727 \\
Asymp. Sig. (2-tailed) & .467 \\
\hline
\end{tabular}

Uji hipotesis 2 dilakukan untuk menguji kuisioner utama berupa essay yang mencerminkan aspek literasi keuangan dari aspek pengetahuan. Berdasarkan hasil analisis statistik diatas Uhitung aspek perilaku sebesar 401.000 lebih besar dari nilai Utabel sebesar 317 dan nilai signifikansinya 0,467 lebih besar dri $\alpha=0,05$. Dari hasil analisis tersebut maka hipotesis kedua yaitu Terdapat Perbedaan literasi keuangan nasabah CU yang mendapat pendidikan keuangan dengan anggota BMT yang tidak mendapat pendidikan keuangan dilihat dari aspek pengetahuan ditolak.

3) Hipotesis 3 
H3: Terdapat perbedaan literasi keuangan nasabah CU yang mendapat pendidikan keuangan dengan nasabah BMT yang tidak mendapat pendidikan keuangan dilihat dari aspek sikap.

HO: Tidak terdapat perbedaan literasi keuangan nasabah CU yang mendapat pendidikan keuangan dengan nasabah BMT yang tidak mendapat pendidikan keuangan dilihat dari aspek sikap.

Hasil Uji Independent Sample Uji Mann Whitney $U$ test Aspek Pengetahuan dapat dilihat dalam tabel sebagai berikut:

Ranks

\begin{tabular}{|l|l|r|r|r|}
\hline & Grup & N & Mean Rank & Sum of Ranks \\
\hline Sikap & 100 & 30 & 27.45 & 823.50 \\
& 200 & 30 & 33.55 & 1006.50 \\
& Total & 60 & & \\
\hline
\end{tabular}

Test Statistics ${ }^{\mathrm{a}}$

\begin{tabular}{|l|l|}
\hline & Sikap \\
\hline Mann-Whitney U & 358.500 \\
Wilcoxon W & 823.500 \\
Z & -1.359 \\
Asymp. Sig. (2-tailed) & .174 \\
\hline
\end{tabular}

Uji hipotesis 3 dilakukan untuk menguji kuisioner utama berupa essay yang mencerminkan aspek literasi keuangan dari aspek sikap. Berdasarkan hasil analisis statistik diatas Uhitung aspek perilaku sebesar 358,800 lebih besar dari nilai Utabel sebesar 317 dan nilai signifikansinya 0,174 lebih besar dri $\alpha=0,05$. Dari hasil analisis tersebut maka hipotesis kedua yaitu Terdapat Perbedaan literasi keuangan nasabah CU yang mendapat pendidikan keuangan dengan anggota BMT yang tidak mendapat pendidikan keuangan dilihat dari aspek sikap ditolak.

\section{Pembahasan}

\section{a. Terdapat Perbedaan literasi keuangan masyarakat anggota CU yang mendapat pendidikan keuangan dengan anggota BT yang tidak mendapat pendidikan keuangan dilihat dari aspek perilaku.}

Berdasarkan hasil analisis statistik uji mann whitney $U$ test terhadap hipotesis 1 dalam penelitian ini menunjukan bahwa literasi keuangan anggota credit union yang mendapatkan pendidikan keuangan dengan anggota BMT yang tidak mendapatkan pendidikan keuangan dilihat dari aspek perilaku tidak terdapat perbedaan. Yang artinya $\mathrm{H} 1$ dalam penelitian ini ditolak. Hal ini memiliki arti bahwa pendidikan keuangan yang diterapkan oleh Credit Union Mino Martani Sokaraja belum mampu meningkatkan literasi keuangan dari aspek perilaku.

Aspek perilaku dalam hipotesis ini mencerminkan beberapa indikator antara lain : adanya anggaran rumah tangga, pengetahuan mengenai jasa keuangan, jasa keuangan yang saat ini digunakan, pilihan jasa keuangan, pertimbangan sebelum melakukan investasi, informasi yang paling berpengaruh terhadap keputusan keuangan, kemampuan pendapatan dalam memenuhi kebutuhan tiap bulannya, cara untuk menutup apabila pendapatan berkurang, cara menyimpan uangnya, kemampuan memulihkan keuangan (recovery ability) dan stabilitas pendapatan. Dari indikator-indikator tersebut yang ditanyakan 
kepada responden di Credit Union dan BMT menunjukan adanya persamaan perilaku.

Anggota Credit Union Mino Martani Sokaraja maupun anggota Baitul Maal Wattamwil Dana Mentari Purwokerto tidak memiliki perbedaan literasi keuangan dilihat dari aspek perilaku. Anggaran rumah tangga secara umum sudah dibuat baik oleh anggota Credit Union maupun anggota BMT. Meskipun anggaran yang dibuat masih sangat sederhana seperti yang diungkapkan pada saat wawancara dengan peneliti. Pengetahuan mengenai jasa keuangan juga sama-sama rendah baik anggota Credit Union maupun anggota BMT. Dalam penentuan berinvestasi pun baik anggota CU maupun anggota Credit Union belum memiliki pertimbangan keuangan hal ini sejalan dengan indikator berikutnya yaitu baik anggota CU maupun anggota BMT belum memiliki sumber informasi yang akurat dalam pengambilan keputusan. Pendapatan yang didapat oleh anggota CU maupun anggota BMT juga sama-sama belum mampu untuk memenuhi kebutuhan sehari-hari. Untuk menutup kekurangan tersebut baik anggota CU maupun anggota BMT lebih memilih untuk megambil simpanan dari tabungan mereka. Anggota CU maupun anggota BMT memiliki cara menabung yang sama-sama masih sedikit, kemampuan menutup kekurangan biaya hidup tanpa berhutang yang cenderung lama baik itu anggota CU maupun anggota BMT dan baik anggota CU maupun anggota BMT memiliki pendapatan yang belum stabil.

b. Terdapat Perbedaan literasi keuangan masyarakat anggota CU yang mendapat pendidikan keuangan dengan anggota BT yang tidak mendapat pendidikan keuangan dilihat dari aspek pengetahuan.

Berdasarkan hasil analisis statistik uji mann whitney $U$ test terhadap hipotesis 2 dalam penelitian ini menunjukan bahwa literasi keuangan anggota Credit Union yang mendapatkan pendidikan keuangan dengan anggota BMT yang tidak mendapatkan pendidikan keuangan dilihat dari aspek pengetahuan tidak terdapat perbedaan. Yang artinya $\mathrm{H} 2$ dalam penelitian ini ditolak. Hal ini memiliki arti bahwa pendidikan keuangan yang diterapkan oleh Credit Union Mino Martani Sokaraja belum mampu meningkatkan literasi keuangan dari aspek pengetahuan.

Aspek pengetahuan dalam hipotesis ini mencerminkan beberapa indikator antara lain : pengetahuan mengenai pembagian keuangan, pengetahuan time value of money, pengetahuan mengenai bunga, dan pengetahuan mengenai risiko investasi. Dari indikator-indikator tersebut yang ditanyakan kepada responden di Credit Union dan BMT menunjukan adanya persamaan dari aspek pengetahuan. Pengetahuan mengenai pembagian keuangan anggota Credit Union maupun anggota BMT sudah baik. Sebagian besar anggota CU maupun BMT mampu menjawab benar mengenai pembagian keuangan. Pengetahuan Time Value Of Money dan Pengetahuan mengenai bunga pinjaman anggota Credit Union maupun anggota BMT masih sama-sama rendah. Pengetahuan mengenai risiko investasi antara anggota $\mathrm{CU}$ dan anggota BMT juga menunjukan angka yang sama-sama masih rendah.

c. Terdapat Perbedaan literasi keuangan masyarakat anggota CU yang mendapat pendidikan keuangan dengan anggota BT yang tidak mendapat pendidikan keuangan dilihat dari aspek sikap. 
Berdasarkan hasil analisis statistik uji mann whitney $U$ test terhadap hipotesis 3 dalam penelitian ini menunjukan bahwa literasi keuangan anggota Credit Union yang mendapatkan pendidikan keuangan dengan anggota BMT yang tidak mendapatkan pendidikan keuangan dilihat dari aspek sikap tidak terdapat perbedaan. Yang artinya H3 dalam penelitian ini ditolak. Hal ini memiliki arti bahwa pendidikan keuangan yang diterapkan oleh Credit Union Mino Martani Sokaraja belum mampu meningkatkan literasi keuangan dari aspek pengetahuan.

Aspek Sikap diukur melalui pertimbangan kemampuan dalam membayar angsuran sebelum membeli barang secara kredit, sikap dalam memikirkan kebutuhan hari ini dan kebutuhan hari besok, prioritas dalam belanja dan menabung, tepat atau tidaknya membayar utang/tagihan, menabung agar mempunyai dana cadangan untuk kondisi darurat, mengontrol sendiri keuangan pribadi, perencanaan keuangan jangka panjang, sikap terhadap uang, setuju atau tidaknya meminjam uang pada rentenir, setuju atau tidaknya meminjam uang pada koperasi, bank atau credit union,asuransi biaya pendidikan dan kesehatan, kepemilikan tabungan masa tua, menabung kalau ada uang sisa dari uang bulanan,prioritas dalam membayar hutang dulu baru kemudian belanja, penjualan harta/barang untuk memenuhi kebutuhan tak terduga.

Anggota CU dan anggota BMT sama-sama memiliki pertimbangan dalam membayar angsuran. Sebagian besar anggota CU dan anggota BMT memikirkan kebutuhan hari ini dan juga hari esok. Anggota BMT maupun anggota CU sebagian besar suka menabung daripada belanja namun mereka tetap memastikan bahwa mereka membayar utang/tagihan tepat waktu. Kedua anggota baik CU maupun BMT menabung sama-sama dengan tujuan untuk mempunyai cadangan untuk kondisi darurat dan sama-sama tidak suka meminjamkan uang pada rentenir. Anggota CU dan anggota BMT sama-sama setuju untuk meminjam uang di Koperasi, Bank atau Credit Union. Setuju dalam mengasuransikan biaya pendidikan dan kesehatan, setuju kepemilikan tabungan masa tua, setuju untuk menabung setiap bulan jika ada sisa dari uang bulanan, prioritas dalam membayar hutang dulu baru kemudian belanja, tidak setuju untuk menjual harta/barang untuk memenuhi kebutuhan tak terduga.

\section{B. KESIMPULAN}

Kesimpulam yang dapat diperoleh dari penelitian ini adalah :

a) Tidak terdapat perbedaan literasi keuangan masyarakat anggota CU yang mendapat pendidikan keuangan dengan anggota BT yang tidak mendapat pendidikan keuangan dilihat dari aspek perilaku.

b) Tidak terdapat perbedaan literasi keuangan masyarakat anggota CU yang mendapat pendidikan keuangan dengan anggota BT yang tidak mendapat pendidikan keuangan dilihat dari aspek pengetahuan.

c) Tidak terdapat perbedaan literasi keuangan masyarakat anggota CU yang mendapat pendidikan keuangan dengan anggota BT yang tidak mendapat pendidikan keuangan dilihat dari aspek sikap.

\section{SARAN}

Penelitian ini hanya menguji perbedaan literasi keuangan anggota CU yang telah mendapat pendidikan keuangan dengan anggota BT yang belum mendapat pendidikan keuangan. Penelitian selanjutnya diharapkan meneliti objek yang berbeda sebelum 
mendapat pendidikan keuangan dan setelah mendapat pendidikan keuangan. Contoh: perbedaan literasi keuangan BMT sebelum mendapat pendidikan keuangan dan setelah mendapat pendidikan keuangan. Penelitian ini hanya mengkaji dari tiga aspek yaitu perilaku, pengetahuan dan sikap sehingga untuk penelitian selanjutnya diharapkan menambahkan variabel seperti jenis kelamin, tingkat pendidikan, dll. Penelitian selanjutnya juga bisa merubah objek penelitian seperti mahasiswa, nasabah LKS, maupun ibu rumah tangga.

\section{DAFTAR PUSTAKA}

Atkinson, Adele \& Flore. 2011. An Internationally Comparable Survey Of Financial Literacy. OECD Paper

Ayub Barombo., Asrori., dan Donatianus. 2012. Pemberdayaan Masyarakat melalui Koperasi Credit Union (CU) (studi kasus: CU Khatulistiwa Bakti Pontianak). Jurnal Tesis. Jurnal Unan, 2012.

Buchori, Nur Syamsudin. 2012. Koperasi Syariah Teori dan Praktik. Pustaka Aufa Media. Tangerang 101.

Ghozali, Imam. 2006. Statistik Non Parametrik: Teori dan Aplikasi dengan Program SPSS. Universitas Diponegoro. Semarang Djazuli, A dan Janwari Yadi. 2002. Lembagalembaga Perekonomian Umat Sebuah Pengenalan. PT. Raja Grafindo Persada. Jakarta

Gay, L. R., and P. L. Diehl. (1996). Research Methods For Business and Management. International Edition. New Jersey: Prentice Hall.

Huston, S.J 2010. Measuring financial literacy. The Jounal of Consumer Affairs. Vol 4 No.2 Widayati,

Irin, 2012. Faktor-Faktor Yang Mempengaruhi Literasi Finansial Mahasiswa Fakultas Ekonomi Dan Bisnis Universitas Brawijaya. ASSET: Jurnal Akuntansi dan Pendidikan, Volume 1, Nomor 1, Oktober 2012

Jogiyanto. 2010. Pedoman Survei Kuesioner: Pengembangan kuesioner, mengatasi bias dan meningkatkan respon. BPFE. Yogyakarta

Kempson, Elaine \& Adele Atkinson. 2008. Overview and assessment of existing measurements of offinancial literacy/capability across the world. Personal Finance Research Centre University Of Bristol. London.

Ketaren, Nurlela. 2007. Faktor-Faktor Yang Mempengaruhi Keberhasilan Koperasi Credit Union dalam Pemberdayaan Masyarakat. Jurnal Analisis Administrasi dan Kebijakan Vol. 1. No. 3

Krishna, Ayu, Dkk, 2010. Analisis Tingkat Literasi Keuangan Di Kalangan Mahasiswa Dan Faktor-Faktor Yang Mempengaruhinya (Survey Pada Mahasiswa Universitas Pendidikan Indonesia).

Munaldus, dkk. 2012, Credit Union: Kendaraan Menuju Kemakmuran, Jakarta: PT. Alex Media Komputindo Kompas Gramedia.

Nababan, Darman dan Isfenti Sadalia, 2012. Analisis Personal Financial Literacy Dan Financial Behavior Mahasiswa Strata I Fakultas Ekonomi Universitas Sumatera Utara

OECD. (2013). PISA 2012 Assassement and Analytical Framework: Mathematics.Reading, Science, Problem Solving and Financial Literacy.

Panggabean, S. Mutiara. 2010. Manajemen Sumber Daya Manusia. Ghalia Indonesia; Jakarta 
Peter, 2012 Analisis Literasi Ekonomi. UKSW-Salatiga Peter G.S dan Ricky A.N. 2011. Apakah Kamu Yakin Memiliki Literasi Keuangan Yang Tinggi? Proceding PESAT (Psikologi, Ekonomi, Sastra, Arsitektur dan Sipil) Universitas Gunadarma 20-21 Oktober 2009. Depok.

Prahalad, C.K. 2004. The Fortune at The Bottom of The Pyramid: Mengentaskan Kemiskinan Sekaligus Memperoleh Laba. Bambang Sarwiji (Ed.). PT Intan sejati Klaten.

Sugiyono, 2009, Metode Penelitian Kuantitatif, Kualitatif dan R\&D, Bandung : Alfabeta.

Suyatno, Thomas. 1988. Dasar-dasar Perkreditan. Gramedia Pustaka Utama. Jakarta Munaldus, dkk. 2013. Hidup Berkelimpahan Bersama Credit Union. PT Gramedia. Jakarta

www.depkop.go.id

www.bps.go.id

www.inkopsyahbmt.co.id

www. kompas.com

www.tempo.co 